\title{
RESPONS SELEKSI INDIVIDU KARAKTER PERTUMBUHAN POPULASI F-0 IKAN MAS STRAIN RAJADANU
}

\author{
Didik Ariyanto, Erma Primanita Hayuningtyas, dan Khairul Syahputra \\ Balai Penelitian Pemuliaan Ikan \\ Jl. Raya 2 Sukamandi, Subang 41256 \\ E-mail: didik_sky@yahoo.com
}

(Naskah diterima: 2 April 2014; Revisi final: 7 Agustus 2014; Disetujui publikasi: 10 November 2014)

\begin{abstract}
ABSTRAK
Program pembentukan varietas unggul ikan mas tahan penyakit khususnya koi herpesvirus (KHV) dilakukan untuk mengatasi penyakit yang mewabah sejak tahun 2002. Hasil evaluasi awal program tersebut menunjukkan bahwa ikan mas strain Rajadanu dari Kabupaten Kuningan, Jawa Barat mempunyai daya tahan terhadap penyakit KHV lebih baik dibandingkan strain lainnya. Namun demikian, hasil evaluasi pada populasi F-0 ikan mas tahan penyakit, yang diindikasikan dengan marka molekuler major histocompatibility complex (MHC) II terkait daya tahan terhadap penyakit, mempunyai laju pertumbuhan relatif lebih lambat. Untuk mengatasi permasalahan tersebut, dilakukan kegiatan seleksi individu karakter pertumbuhan pada populasi F-0 ikan mas strain Rajadanu yang mempunyai marka MHC. Penelitian ini bertujuan untuk mengevaluasi respons seleksi individu karakter pertumbuhan pada populasi F-0 ikan mas strain Rajadanu terhadap keragaan pertumbuhan benih F-1. Benih F-1 dari induk terseleksi dan kontrol berumur tiga bulan dengan bobot individu 10-15 g dipelihara di kolam pembesaran ukuran $50 \mathrm{~m}^{2}$ dengan kepadatan $10 \mathrm{ekor} / \mathrm{m}^{2}$. Pakan komersial berbentuk pelet dengan kandungan protein kasar $28 \%$ diberikan sebanyak 10\%; 7,5\%; 5\%; dan 2,5\% dari total biomassa ikan per hari pada bulan pertama, kedua, ketiga, dan keempat. Pakan diberikan dua kali sehari setiap pagi dan sore. Sampling bobot rata-rata individu dilakukan setiap bulan hingga akhir bulan keempat. Selain sampling bobot, pada akhir bulan keempat juga dilakukan penghitungan jumlah individu yang hidup untuk menganalisis nilai sintasan dan biomassa panen. Hasil penelitian menunjukkan bahwa selisih bobot rata-rata individu populasi F-1 hasil seleksi dengan kontrol sebesar 17,84 $\mathrm{g}$ atau setara dengan respons seleksi sebesar 7,29\%. Nilai heritabilitas nyata karakter pertumbuhan populasi ikan mas strain Rajadanu dalam penelitian ini termasuk kategori rendah, sebesar 0,06.
\end{abstract}

KATA KUNCI: ikan mas, seleksi individu, pertumbuhan, respons seleksi

ABSTRACT: Response of individual selection for growth character of base population (F-O) of Rajadanu strain of common carp. By: Didik Ariyanto, Erma Primanita Hayuningtyas, and Khairul Syahputra

Common carp is one of the most cultured fish species. Establishment of the koi herpesvirus (KHV) resistance line of common carp must be conducted to overcome the outbreak of its since 2002. Early study reported that Rajadanu strain of common carp which originated from Kuningan District of West Java Province has higher resistance to KHV disease than others. However, another report showed that common carp population which has high performance in resistance to specific disease, indicated 
with molecular genetic marker major histocompatibility complex (MHC), has lower performance in other characters especially in growth. This study was conducted to evaluate the response to individual selection for growth character of base population (F-O) of Rajadanu strain of common carp. Three months age F-1 from selected and non-selected brood-stock of common carp base population which individual body weight of about 10-15 g were grown up in earthen ponds sized $50 \mathrm{~m}^{2}$. Rearing density in each pond was 10 fish. $\mathrm{m}^{-2}$. All fish were fed twice daily with commercial diet (crude protein of 28\%), at 10\%; 7.5\%; 5\%, and 2.5\% total biomass of fish, in the $1^{\text {st }}, 2^{\text {nd }}$, $3^{\text {rd }}$, and $4^{\text {th }}$ month, respectively. At the end of the experiment, 50 samples of fish in two populations were weighed to know the average body weight of fish and to estimates the biomass at harvest. The result showed that difference body weight of F-1 between selected and non selected fish was about $17.84 \mathrm{~g}$, equivalent with response to selection $7.29 \%$. Realized heritability of growth character of Rajadanu strain of common carp in this study was low, about 0.06 .

\section{KEYWORDS: common carp, individual selection, growth, response to selection}

\section{PENDAHULUAN}

Ikan mas (Cyprinus carpio) merupakan salah satu jenis ikan perairan tawar yang mempunyai peranan penting dalam kegiatan budidaya. Ikan mas merupakan jenis ikan budidaya utama di beberapa negara seperti di China, India, Israel, dan beberapa negara di kawasan Eropa Timur. Di Indonesia, budidaya ikan mas sudah dimulai sejak abad ke-19. Beberapa daerah yang menjadi sentra budidaya ikan mas antara lain di Jawa Barat, Sumatera Barat, Sumatera Utara, Sulawesi Utara, dan Nusa Tenggara Barat. Dari beberapa sentra budidaya tersebut, Jawa Barat, dan Sumatera Barat merupakan sentra terbesar ikan mas di Indonesia. Hingga tahun 1996, produksi ikan mas menempati urutan pertama dari semua jenis ikan budidaya air tawar nasional.

Pengembangan budidaya ikan mas mengalami kendala yang sangat serius sejak terjadinya wabah penyakit koi herpesvirus (KHV) yang menyerang ikan mas dan koi pada tahun 2002. Wabah penyakit ini mengakibatkan kerugian yang sangat besar di tingkat pembudidaya ikan mas dan koi. Rukmono (2005) dan Sunarto (2005) melaporkan bahwa kerugian yang dialami pembudidaya di beberapa sentra budidaya ikan mas mencapai 10-15 miliar/tahun. Akibat wabah penyakit ini, produksi ikan mas nasional mengalami penurunan yang signifikan. Hal ini terlihat dari rendahnya jumlah produksi ikan mas di setiap sentra produksi.

Dalam rangka menanggulangi masalah tersebut, Balai Penelitian Pemuliaan Ikan, Sukamandi melakukan kegiatan pemuliaan ikan mas yang bertujuan menghasilkan varietas unggul ikan mas tahan KHV. Kegiatan dimulai dari koleksi plasma nutfah (Ariyanto et al., 2010), dilengkapi dengan karakterisasi spesifik masing-masing plasma nutfah (Hayuningtyas et al., 2011) dan dilanjutkan dengan evaluasi plasma nutfah tersebut terutama terkait dengan daya tahannya terhadap penyakit, khususnya KHV (Ariyanto et al., $2011 b)$.

Hasil evaluasi secara laboratorium menunjukkan bahwa plasma nutfah ikan mas dari Kabupaten Kuningan, Jawa Barat yaitu ikan mas strain Rajadanu mempunyai daya tahan relatif lebih baik dibandingkan strain lainnya (Ariyanto et al., $2011 \mathrm{~b}$ ). Namun demikian, Hayuningtyas et al. (2013) melaporkan bahwa populasi ikan mas strain Rajadanu mempunyai daya tahan terhadap penyakit lebih tinggi, diindikasikan dengan marka molekuler major histocompatibility complex (MHC) II tekait ketahanan terhadap penyakit, mempunyai laju pertumbuhan lebih lambat dibandingkan populasi yang tidak mempunyai marka tersebut. Dalam rangka mengatasi permasalahan tersebut, telah dilakukan kegiatan seleksi individu karakter pertumbuhan pada populasi F-0 ikan mas Rajadanu yang mempunyai marka MHC (Ariyanto et al., 2011 a).

Penelitian ini bertujuan untuk mengevaluasi respons seleksi individu karakter pertumbuhan populasi F-0 ikan mas strain Rajadanu. Selain itu, penelitian ini juga untuk memverifikasi nilai heritabilitas karakter pertumbuhan ikan mas strain Rajadanu melalui penghitungan heritabilitas dalam arti nyata. 


\section{BAHAN DAN METODE}

\section{Pembentukan dan Seleksi Populasi F-0}

Pembentukan populasi dasar ( $\mathrm{F}-0)$ dilakukan pada tahun 2011 . Populasi dasar ini dibentuk dari pemijahan tetua $(P)$ ikan mas strain Rajadanu yang diperoleh dari kegiatan koleksi plasma nutfah tahun 2010. Tetua ikan mas strain Rajadanu berasal dari populasi "survivor" ikan mas strain Rajadanu di sentra budidaya di Waduk Cirata, Cianjur, Jawa Barat ketika terjadi wabah KHV pada tahun 2007. Populasi dasar (F-0) dibentuk dari induk jantan dan betina terseleksi berdasarkan marka molekuler MHC sebagai gen penyandi ketahanan terhadap penyakit, khususnya KHV. Populasi dasar (F-0) terdiri atas 20 famili yang bersifat full-sib, yaitu 20 ekor jantan masingmasing dipijahkan dengan 20 ekor betina. Tahap pemeliharaan larva dan pendederan benih dilakukan secara terpisah antar famili. Pada akhir masa pendederan, diambil secara acak 200 ekor benih dari setiap famili untuk dibesarkan sebagai calon induk. Kegiatan pembesaran dilakukan secara komunal di kolam tanah ukuran $400 \mathrm{~m}^{2}$ selama empat bulan. Pakan yang diberikan merupakan pakan komersial berbentuk pelet dengan kandungan protein kasar $28 \%$. Jumlah pakan sebanyak $10 \%$; 7,5\%; $5 \%$; dan 2,5\% dari biomassa ikan diberikan pada bulan pertama, kedua, ketiga, dan keempat. Pakan diberikan setiap hari dengan frekuensi dua kali sehari setiap pagi pada pukul 9.0-10.0 dan sore pada pukul 15.30-16.30.

Pada saat ukuran benih mencapai 200$300 \mathrm{~g} /$ ekor, dilakukan seleksi individu karakter bobot calon induk F-0. Sampling bobot individu dilakukan untuk menentukan bobot minimal individu terseleksi. Jumlah sampel sebanyak 200 ekor ditimbang dan diurutkan dari bobot tertinggi hingga terendah. Berdasarkan urutan bobot individu tersebut selanjutnya diseleksi $20 \%$ individu dengan bobot tertinggi. Berdasarkan metode tersebut diperoleh bobot minimal individu terseleksi sebesar $400 \mathrm{~g}$, sehingga semua individu calon induk F-0 dengan bobot lebih dari $400 \mathrm{~g}$ dipilih dan dipelihara lebih lanjut sebagai calon induk terseleksi. Sebagai populasi kontrol, dipilih individu-individu calon induk dengan bobot rata-rata populasi, yaitu sebesar 200-300 g. Jumlah individu dalam populasi kontrol sebanyak $5 \%$ dari total populasi calon induk. Masing-masing populasi calon induk tersebut selanjutnya dipelihara secara ter- pisah antara jantan dan betina. Pakan yang diberikan berupa pelet komersial dengan kandungan protein $40 \%$. Pakan diberikan dua kali sehari sebanyak $2 \%$ dari biomassa ikan.

\section{Pembentukan Benih Uji F-1}

Pemilihan induk pada populasi F-0 terseleksi dan kontrol dilakukan untuk mendapatkan tingkat kematangan gonad yang relatif seragam. Dua pasang induk yang terpilih dari masing-masing populasi dipisahkan dalam bak penampung induk berukuran $2 \mathrm{~m} \times 2 \mathrm{~m} \times$ $0,8 \mathrm{~m}$ di dalam hatcheri yang diberi tambahan aerasi dan sistem resirkulasi air. Pemijahan dilakukan dengan sistem pemijahan buatan. Hormon perangsang pemijahan $\left(\right.$ Ovaprim $\left.^{\circledR}\right)$ disuntikkan secara intramuskuler dengan dosis $0,3 \mathrm{~mL} / \mathrm{kg}$ bobot induk betina dan $0,15 \mathrm{~mL} /$ $\mathrm{kg}$ bobot induk jantan. Pengecekan ovulasi dilakukan setiap setengah jam, setelah delapan jam pasca penyuntikan. Telur hasil stripping ditampung dalam wadah dan difertilisasi dengan sperma yang diperoleh dari induk jantan dengan cara stripping. Telur yang sudah difertilisasi selanjutnya ditebar pada media penempelan telur berupa kakaban yang terbuat dari ijuk yang dijepit dua bilah bambu. Kakaban ditempatkan di bak penetasan telur ukuran $2 \mathrm{~m} \times 1 \mathrm{~m} \times 0,8 \mathrm{~m}$ dengan kedalaman air $60 \mathrm{~cm}$. Setiap bak penetasan telur dilengkapi dengan aerasi buatan dari electric blower dan sistem resirkulasi air. Telur menetas menjadi larva kurang lebih tiga hari setelah pemijahan. Larva yang berumur 2-3 hari setelah menetas dipindahkan dari masing-masing bak penetasan ke dalam bak pemeliharaan larva dengan kepadatan 1.000 ekor $/ \mathrm{m}^{2}$.

\section{Pemeliharaan Larva dan Benih}

Sebelum penebaran larva, kolam pemeliharaan berupa bak beton ukuran 2,5 $\mathrm{m} \times 10 \mathrm{~m}$ $x 1$ m disiapkan dengan cara membersihkan kotoran dan mengisi air hingga kedalaman $20 \mathrm{~cm}$. Tahap selanjutnya adalah pemberian pupuk organik sebanyak $200 \mathrm{~g} / \mathrm{m}^{2}$ untuk menumbuhkan pakan alami bagi larva yang akan ditebar. Setelah tiga hari, air akan berubah warna menjadi hijau sebagai indikator telah tumbuhnya pakan alami. Kedalaman air ditambahkan dengan cara mengalirkan air ke dalam bak hingga mencapai kedalaman $80 \mathrm{~cm}$. Dua hari setelah itu, bak pendederan siap digunakan. Selama kegiatan pemeliharaan larva dan benih, bak dilengkapi dengan sistem 
aerasi buatan menggunakan electric hi-blower dan aliran air dengan debit sekitar 0,25 L/detik.

Larva berumur 2-3 hari setelah menetas di dalam hatcheri dipindahkan ke dalam bak pemeliharaan dengan kepadatan 1.000 ekor/ $\mathrm{m}^{2}$. Pemberian pakan buatan komersial berbentuk serbuk dengan kandungan protein kasar $40 \%$ dilakukan mulai hari ke-3 setelah penebaran larva. Pakan buatan diberikan secara merata di permukaan kolam dengan frekuensi dua kali sehari secara ad libitum. Setelah pemeliharaan selama satu bulan, benih dipindahkan ke kantong hapa ukuran 2,5 $\mathrm{m} \times$ 2,5 $\mathrm{m} \times 1 \mathrm{~m}$ yang ditempatkan di kolam tanah dengan kepadatan 500 ekor/hapa. Selama satu bulan pemeliharaan di dalam kantong hapa, benih diberi pakan buatan komersial berbentuk remah dengan kandungan protein kasar sebesar 30\%-32\%. Pakan diberikan dua kali sehari pagi dan sore secara ad libitum. Pada akhir pemeliharaan, benih dipindahkan ke kantong waring ukuran $3 \mathrm{~m} \times 5 \mathrm{~m} \times 1,5 \mathrm{~m}$ yang ditempatkan di kolam tanah dengan kepadatan 100 ekor/waring. Selama satu bulan pemeliharaan di dalam kantong waring, benih diberi pakan komersial berbentuk pelet dengan kandungan protein kasar sebesar 28\%$30 \%$. Pakan diberikan dua kali sehari pagi dan sore, sekenyangnya (at satiation).

\section{Pengujian Pertumbuhan}

Benih hasil pemeliharaan di kantong waring dengan bobot rata-rata individu 10-15 g/ ekor digunakan sebagai bahan uji pertumbuhan populasi F-1 ikan mas hasil seleksi dan kontrol. Pengujian dilakukan di kolam tanah ukuran $50 \mathrm{~m}^{2}$ dengan kedalaman air 60-70 $\mathrm{cm}$. Jumlah kolam yang digunakan sebanyak enam unit, yakni untuk dua populasi benih dengan tiga kali ulangan. Benih uji ditebar dengan kepadatan 10 ekor $/ \mathrm{m}^{2}$. Pakan yang diberikan selama masa pengujian merupakan pakan komersial berbentuk pelet dengan kandungan protein kasar $28 \%$. Jumlah pakan sebanyak $10 \%$; $7,5 \%$; $5 \%$; dan $2,5 \%$ dari biomassa ikan diberikan masing-masing pada empat minggu pertama, kedua, ketiga, dan keempat. Pakan diberikan setiap hari dengan frekuensi dua kali sehari, setiap pagi (pukul 09.00-10.00) dan sore (pukul 15.30-16.30).

\section{Parameter Uji dan Analisis Data}

Data bobot rata-rata individu benih ikan mas pada masing-masing populasi uji diperoleh dengan cara sampling setiap bulan. Jum- lah sampel individu sebanyak 50 ekor setiap ulangan. Pada akhir bulan keempat dilakukan sampling bobot rata-rata individu, analisis sintasan, serta estimasi nilai biomassa total panen pada masing-masing populasi. Analisis sintasan dilakukan dengan menghitung jumlah total benih ikan uji yang hidup pada akhir percobaan dibagi dengan jumlah benih di awal percobaan. Estimasi nilai biomassa total panen dilakukan dengan mengalikan jumlah benih ikan uji yang hidup di akhir percobaan dengan bobot rata-rata individu.

Analisis statistik untuk menguji perbedaan bobot rata-rata individu, nilai sintasan, dan biomassa total panen antara populasi benih F-1 terseleksi dengan kontrol dilakukan dengan uji F pada taraf $\pm=0,05$. Data bobot rata-rata individu juga digunakan untuk menganalisis nilai specific growth rate (SGR) dan respons seleksi karakter pertumbuhan dari populasi F-0 ke F-1, serta nilai heritabilitas nyata karakter pertumbuhan populasi hasil seleksi populasi F-0. Data SGR, respons seleksi dan heritabilitas nyata populasi ikan mas dianalisis secara deskriptif. Untuk mengetahui kemungkinan adanya pengaruh lingkungan terhadap performa benih F-1, dalam makalah ini disajikan hasil pemeliharaan populasi F-0 yang dilakukan oleh Ariyanto et al. (2011).

$$
\mathrm{SGR}=\frac{\ln \mathrm{Wt}-\ln \mathrm{Wo}}{\mathrm{t}} \times 100 \%
$$

di mana:

$$
\begin{aligned}
\text { SGR } & =\text { Laju pertumbuhan spesifik (\%) } \\
\text { Wo } & =\text { Bobot awal } \\
W t & =\text { Bobot pada waktu } \mathrm{t} \\
\mathrm{t} & =\text { Waktu pemeliharaan }
\end{aligned}
$$

$$
\text { Respons seleksi }(\mathrm{R})=\mathrm{X}(\mathrm{F}-1)-\mathrm{X}(\mathrm{F}-0)
$$

di mana:

$$
X(F-1)=\text { Bobot rata-rata benih terseleksi }
$$$$
X(F-0)=\text { Bobot rata-rata benih kontrol }
$$

$$
\text { Heritabilitas nyata }\left(h^{2}\right)=R / S
$$

di mana:

$\mathrm{R}=$ Respons seleksi

$\mathrm{S}=$ Diferensial seleksi populasi F-0

\section{HASIL DAN BAHASAN}

\section{Laju Pertumbuhan}

Pengujian laju pertumbuhan digunakan untuk mengevaluasi respons seleksi karakter 
pertumbuhan yang diindikasikan dengan bobot rata-rata individu antar generasi. Dalam kegiatan ini, yang dianalisis adalah respons seleksi individu pada induk ikan mas F-0 terhadap laju pertumbuhan benih F-1 yang dihasilkan. Hasil pengamatan performa benih ikan mas F-1 terseleksi dan kontrol disajikan pada Tabel 1.

Hasil analisis SGR populasi benih ikan mas F-1 terseleksi sebesar 2,40\%/hari; sedangkan SGR populasi kontrol sebesar 2,30\%/hari. Nilai yang diperoleh pada penelitian ini jauh lebih baik dibandingkan dengan laju pertumbuhan F-0 yang diperoleh pada penelitian sebelumnya sebesar 2,09\%/hari (Ariyanto et al., 2011 a). Berdasarkan Tabel 1 terlihat bahwa populasi benih F-1 terseleksi dan kontrol mempunyai peningkatan bobot rata-rata individu lebih baik dibandingkan populasi benih $\mathrm{F}-0$. Peningkatan performa pertumbuhan populasi kontrol dibandingkan F-0 mengindikasikan adanya perbedaan kondisi lingkungan dan atau teknologi yang digunakan pada waktu pemeliharaan populasi benih F-0 tahun 2011 dengan populasi F-1 tahun 2012. Jika kondisi lingkungan dan teknologi yang diaplikasikan dalam pemeliharaan kedua populasi tersebut sama atau setara, maka secara teori performa kedua populasi tersebut mestinya sama. Hal ini karena populasi kontrol merupakan representasi dari populasi F-0.

Berdasarkan data pada Tabel 1, peningkatan bobot akhir benih F-1 terseleksi dibandingkan F-0 sebesar 52,31 g. Hasil ini mengindikasikan adanya peningkatan performa pertumbuhan populasi ikan mas F-1 terseleksi dari F-0 sebesar $24,90 \%$. Namun demikian, adanya peningkatan performa pertumbuhan populasi kontrol dibandingkan F-0 sebesar $34,5 \mathrm{~g}$ atau setara dengan $17,84 \%$ menguatkan dugaan adanya perbedaan lingkungan dan atau teknologi budidaya yang diaplikasikan pada pemeliharaan populasi F-0 dan F-1. Berdasarkan analisis ini, peningkatan performa pertumbuhan $\mathrm{F}-1$ terseleksi terhadap $\mathrm{F}-0$ sebesar $24,90 \%$ diduga dipengaruhi oleh dua faktor, yakni faktor genetik sebesar 7,29\% dan faktor lingkungan sebesar 17,61\%.

Faktor lingkungan yang dapat berpengaruh terhadap performa pertumbuhan benih ikan mas pada penelitian ini antara lain kondisi lingkungan seperti cuaca, musim, kondisi kolam, jenis, dan jumlah kandungan nutrisi dalam pakan, serta kualitas air sebagai media pemeliharaan ikan. Populasi F-0 dipelihara pada akhir musim hujan hingga memasuki musim kemarau, yakni dari bulan Februari-Juni 2011 (Ariyanto et al., 2011 a), sedangkan populasi F-1 dipelihara pada akhir musim kemarau di bulan Agustus 2012 hingga memasuki musim penghujan pada bulan November 2012 . Perbedaan kondisi klimatologi selama periode pemeliharaan kedua populasi tersebut diduga berpengaruh terhadap keragaan benih ikan mas. Selain kondisi klimatologi, salah satu komponen teknologi yang berbeda antara kedua percobaan tersebut adalah luasan kolam yang digunakan. Populasi F-0 dipelihara pada kolam seluas $400 \mathrm{~m}^{2}$, sedangkan populasi F- 1 dipelihara pada kolam seluas $50 \mathrm{~m}^{2}$. Secara umum, perbedaan luasan kolam yang signifikan akan berdampak terhadap manajemen pemeliharaan ikan. Kolam dengan luasan yang lebih kecil akan lebih memudahkan dalam hal pengelolaannya, baik pengelolaan air maupun hama, penyakit, dan binatang pengganggu lainnya dibandingkan kolam yang lebih besar.

Tabel 1. Keragaan benih ikan mas F-1 terseleksi dan kontrol yang dipelihara selama empat bulan di kolam tanah

Table 1. Performance of selected and control population of F-1 of common carp cultured in earthern ponds for four months

\begin{tabular}{lccc}
\hline \multicolumn{1}{c}{$\begin{array}{c}\text { Parameter } \\
\text { Parameters }\end{array}$} & $\begin{array}{c}\text { F-1 terseleksi } \\
\text { Selected F-1 }\end{array}$ & $\begin{array}{c}\text { Kont rol } \\
\text { Control }\end{array}$ & F-0* \\
\hline Bobot awal (Initial body weight) (g) & $30.00 \pm 0.00$ & $30.00 \pm 0.00$ & $30.00 \pm 0.00$ \\
$\begin{array}{l}\text { Bobot akhir (Final body weight) (g) } \\
\text { Laju pertumbuhan spe sifik (\%/hari) } \\
\text { Specific growth rate (\%/day) }\end{array}$ & $262.56 \pm 71.29$ & $244.72 \pm 11.41$ & 210.22 \\
\hline
\end{tabular}




\section{Respons Seleksi dan Heritabilitas}

Keragaan benih F-1 terseleksi dan kontrol, serta nilai respons seleksi dan analisis heritabilitas nyata karakter pertumbuhan populasi ikan mas strain Rajadanu disajikan pada Tabel 2 . Perhitungan nilai heritabilitas nyata menggunakan nilai diferensial seleksi populasi F-0 sebesar 283,33 (Ariyanto et al., 2011 a).

Berdasarkan Tabel 2, terlihat bahwa nilai estimasi heritabilitas dan prediksi respons seleksi yang diperoleh pada penelitian sebelumnya berbeda dengan nilai yang diperoleh pada penelitian ini. Heritabilitas estimasi yang diperoleh pada penelitian Ariyanto et al. (2011a) adalah heritabilitas dalam arti luas (broad sense heritability). Tave (1993) dan Noor (2000) menjelaskan bahwa heritabilitas estimasi dalam arti luas dilakukan dengan melibatkan analisis variasi genetik total $\left(\mathrm{V}_{\mathrm{C}}\right)$, yang terdiri atas variasi genetik aditif $\left(V_{A}\right)$ dan non-aditif yang meliputi variasi genetik dominan $\left(V_{D}\right)$ dan epistasi $\left(V_{E}\right)$. Secara teori, daya penurunan gen dominan dan epistasi tidak semutlak aksi gen aditif (Noor, 2000) karena dipengaruhi oleh faktor lingkungan. Dalam pelaksanaannya, penelitian Ariyanto et al. (2011) belum dapat memisahkan antara faktor lingkungan dengan genetik secara jelas se- hingga diduga memengaruhi nilai heritabilitas yang diperoleh. Pada penelitian ini, analisis heritabilitas dilakukan pada heritabilitas dalam arti nyata/sempit (narrow sense heritability). Analisis ini dilakukan berdasarkan performa riil yang diperoleh melalui pengujian di lapangan. Analisis heritabilitas dalam arti nyata hanya melibatkan variasi genetik aditif $\left(V_{A}\right)$ saja tanpa melibatkan variasi genetik dominan $\left(V_{D}\right)$ dan epistasi $\left(V_{E}\right)$ pada populasi. Karena daya penurunan gen dominan dan epistasi tidak semutlak aksi gen aditif, maka evaluasi performa benih F-1 dan kontrol yang merupakan benih dari induk terseleksi dan non-seleksi F-O ini lebih tepat dilakukan melalui pendekatan heritabilitas dalam arti nyata. Hal ini karena variasi genetik aditif $\left(V_{A}\right)$ merupakan fungsi dari alel yang akan diturunkan melalui gamet haploid dari generasi ke generasi. Variasi genetik aditif $\left(V_{A}\right)$ bersifat masing-masing gen menambah sifat-sifat tertentu dari suatu karakter, dengan kata lain setiap alel bersamasama dengan kemampuan berbeda membentuk variasi fenotipik $\left(\mathrm{V}_{\mathrm{p}}\right)$. Seleksi tidak menciptakan gen baru, namun eksploitasi variasi genetik aditif $\left(\mathrm{V}_{\mathrm{A}}\right)$ akan merubah frekuensi gen sehingga meningkatkan mutu genetik secara kualitatif dan kuantitatif dengan sasaran akhir adalah mendapatkan induk unggul

Tabel 2. Bobot rata-rata benih, respons seleksi, dan heritabilitas karakter pertumbuhan populasi ikan mas yang dipelihara selama 112 hari di kolam

Table 2. Average of body weight, response to selection, and heritability of growth of common carp for 112 days cultured in earthern ponds

\begin{tabular}{|c|c|}
\hline $\begin{array}{l}\text { Parameter } \\
\text { Parameters }\end{array}$ & $\begin{array}{l}\text { Nilai terukur } \\
\text { Observed values }\end{array}$ \\
\hline $\begin{array}{l}\text { Bobot rata-rata F-1 terseleksi } \\
\text { Average body weight of selected F-1 (g) }\end{array}$ & $262.56 \pm 71.29$ \\
\hline $\begin{array}{l}\text { Bobot rata-rata F-1 kontrol } \\
\text { Average body weight of control F-1 (g) }\end{array}$ & $244.72 \pm 11.41$ \\
\hline Selisih bobot (Weight differences) (g) & 17.84 \\
\hline Respons seleksi (Response to selection) (\%) & 7.29 \\
\hline Heritabilitas nyata (Realized heritability) & 0.06 \\
\hline $\begin{array}{l}\text { Prediksi respons seleksi } \\
\text { Prediction of response to selection (\%) }\end{array}$ & $103.57^{*}$ \\
\hline $\begin{array}{l}\text { Estimasi he ritabilitas arti luas } \\
\text { Broad sense of estimated heritability }\end{array}$ & $3.4^{*}$ \\
\hline
\end{tabular}


sebagai tetua. Peningkatan mutu genetik ( $g e$ netic gain) pada induk melalui seleksi akan mengubah rata-rata populasi turunannya ke arah yang lebih baik (Hardjosubroto, 1994; Warwick et al., 1995).

Nilai respons seleksi yang diperoleh pada penelitian Ariyanto et al. (2011 a) bersifat estimasi, yaitu dengan mengalikan nilai heritabilitas arti luas yang diperoleh dengan nilai diferensial seleksi populasi F-0. Pada penelitian ini, nilai respons seleksi bersifat nyata, diperoleh dari selisih bobot rata-rata benih F-1 terseleksi dengan kontrol, yaitu sebesar 7,29\%. Nilai ini lebih rendah jika dibandingkan pernyataan Falconer \& Mackay (1996) dan Tave (1996) yang menyatakan bahwa kegiatan seleksi pada setiap generasi induk akan menghasilkan respons rata-rata sebesar $10 \%$. Hulata (1995) menjelaskan bahwa secara umum, seleksi karakter kuantitatif seperti pertumbuhan pada populasi ikan mas tidak memberikan respons yang baik. Beberapa kegiatan seleksi yang dilakukan oleh Moav \& Wohlfarth (1976) juga mendapatkan respons seleksi yang tinggi. Dijelaskan lebih lanjut bahwa seleksi individu yang dilakukan pada ikan mas sampai generasi ke-enam tidak memberikan respons seleksi yang nyata. Hal ini diduga karena laju pertumbuhan pada ikan mas lebih banyak dipengaruhi oleh variasi antar kelompok daripada variasi individu di dalam kelompok. Hal ini mengakibatkan seleksi pertumbuhan yang didasarkan pada variasi antar individu dalam suatu kelompok kemungkinan tidak akan memberikan respons yang signifikan. Selain itu menurut Moav (1979), pada sebagian besar populasi ikan mas, variasi genetik yang berperan cukup besar terhadap performa karakter pertumbuhan adalah variasi genetik non-aditif terutama variasi genetik over-dominan. Ditambahkan oleh Brody et al. (1980) bahwa tidak adanya respons seleksi tersebut banyak disebabkan oleh tidak ditemukannya variasi genetik aditif $\left(V_{A}\right)$ yang disebabkan karena kesalahan pada proses domestikasi. Purdom (1993) juga menambahkan bahwa selain faktor genetik, dugaan kuat tidak terkontrolnya faktor eksternal pada kegiatan seleksi ikan mas juga berdampak terhadap tidak adanya peningkatan performa pada generasi berikutnya.

Selain faktor-faktor tersebut di atas, relatif rendahnya respons seleksi pada populasi ikan mas strain Rajadanu F-1 terseleksi ini diduga juga sebagai dampak relatif rendahnya intensitas seleksi populasi F-0. Ariyanto et al. (2011a) menjelaskan bahwa nilai intensitas seleksi populasi ikan mas F-0 sebesar 1,4. Nilai ini diperoleh berdasarkan nilai persentase seleksi sebesar $20 \%$. Tingginya nilai persentase seleksi pada populasi tersebut dilakukan berdasarkan pertimbangan antara lain relatif terbatasnya jumlah individu dalam populasi F-0. Jika nilai persentase seleksi diturunkan untuk mendapatkan nilai intensitas seleksi yang lebih tinggi dikhawatirkan akan memperkecil jumlah induk-induk terseleksi. Keterbatasan jumlah induk terseleksi sangat berpengaruh terhadap intensitas pemijahan untuk pembentukan generasi berikutnya. Salah satu dampak intensitas pemijahan yang tinggi pada induk-induk dengan jumlah terbatas adalah tingginya laju inbreeding antar generasi yang secara signifikan akan menurunkan fitness populasi (Falconer \& Mackay, 1996; Andersen \& Hayes, 2004; Fjalestad, 2004; Sonesson et al., 2004).

Respons seleksi karakter pertumbuhan populasi ikan mas strain Rajadanu yang rendah mengindikasikan bahwa seleksi individu yang dilakukan pada populasi induk F-0 kurang efektif. Hal ini diduga karena nilai heritabilitas nyata pada karakter tersebut berada dalam kategori rendah $(<20 \%)$. Berdasarkan hasil analisis pada penelitian ini disarankan melanjutkan kegiatan seleksi menggunakan metode seleksi famili atau seleksi kombinasi. Hal ini untuk meningkatkan efektivitas kegiatan seleksi ikan mas strain Rajadanu sebagai kandidat ikan mas tahan KHV pada generasi selanjutnya.

\section{Sintasan dan Biomassa Panen}

Pada akhir masa pembesaran, selain dilakukan analisis bobot rata-rata individu juga dilakukan analisis sintasan dan estimasi nilai biomassa total pada waktu panen. Hasil analisis sintasan dan total biomassa panen disajikan pada Tabel 3.

Hasil analisis secara statistik menunjukkan bahwa kedua populasi mempunyai bobot ratarata individu, sintasan, dan biomassa total pada waktu panen tidak berbeda nyata. Hal ini mengindikasikan bahwa kualitas genetik, serta kondisi lingkungan yang berperan dalam menentukan penampilan fenotipik kedua populasi tidak berbeda. Secara umum, kondisi lingkungan pemeliharaan kedua populasi benih uji pada penelitian ini disajikan pada Tabel 4. 
Tabel 3. Bobot rata-rata individu, sintasan, dan estimasi biomassa ikan mas pada waktu panen Table 3. Average body weight, survival rate, and total biomass estimation at harvest

\begin{tabular}{lccc}
\hline $\begin{array}{c}\text { Populasi } \\
\text { Populations }\end{array}$ & $\begin{array}{c}\text { Bobot rata-rata } \\
\text { Average body weight }\end{array}$ & $\begin{array}{c}\text { Sintasan } \\
\text { Survival rate (\%) }\end{array}$ & $\begin{array}{c}\text { Biomassa total } \\
\text { Total biomass (kg) }\end{array}$ \\
\hline $\begin{array}{l}\text { F-1 terseleksi } \\
\text { Selected F-1 }\end{array}$ & $262.56 \pm 71.29^{\mathrm{a}}$ & $66.6 \pm 14.1^{\mathrm{a}}$ & $92.20 \pm 9.90^{\mathrm{a}}$ \\
Kontrol (Control) & $244.72 \pm 11.41^{\mathrm{a}}$ & $66.1 \pm 14.3^{\mathrm{a}}$ & $89.36 \pm 17.21^{\mathrm{a}}$ \\
\hline
\end{tabular}

Keterangan (Note):

Nilai \pm SE (3 kali ulangan). Nilai diikuti dengan huruf superscript yang sama pada kolom yang sama tidak berbeda nyata pada $\pm=0,05$ (Values \pm SE (three replications). The values followed by same character in the same column was not significantly different at $\pm=0.05)$ )

Tabel 4. Kualitas air media pemeliharaan populasi benih ikan mas F-1 terseleksi dan non-seleksi selama masa pengujian

Table 4. Water ponds quality of selected and non selected F-1 population of common carp

\begin{tabular}{lccc}
\hline \multicolumn{1}{c}{$\begin{array}{c}\text { Parameter } \\
\text { Parameters }\end{array}$} & $\begin{array}{c}\text { Kolam benih F-1 } \\
\text { terseleksi } \\
\text { Ponds of selected F-1 }\end{array}$ & $\begin{array}{c}\text { Kolam benih F-1 } \\
\text { kont rol } \\
\text { Ponds of control F-1 }\end{array}$ & $\begin{array}{c}\text { Referensi" } \\
\text { Reference }\end{array}$ \\
\hline $\begin{array}{l}\text { Suhu (Temperature) }\left({ }^{\circ} \mathrm{C}\right) \\
\text { Oksigen terlarut }\end{array}$ & $27.80-30.17$ & $27.60-30.23$ & $25.0-32.0$ \\
$\begin{array}{l}\text { Dissolved oxygen (mg/L) } \\
\text { pH }\end{array}$ & $2.03-2.26$ & $1.40-2.75$ & $>5$ \\
Amoniak (Ammonia) $(\mathrm{mg} / \mathrm{L})$ & $7.04-7.80$ & $7.05-7.87$ & $6.5-9.0$ \\
Nitrit (Nitrite) $(\mathrm{mg} / \mathrm{L})$ & --- & --- & $<0.5$ \\
\hline
\end{tabular}

Sumber (Source): " Boyd (1990)

Berdasarkan nilai-nilai referensi dari Boyd (1990) untuk budidaya ikan secara umum, terlihat bahwa parameter-parameter kualitas air media pemeliharaan benih ikan mas F- 1 masih berada dalam kisaran nilai yang dapat ditoleransi oleh ikan budidaya. Kualitas air media pemeliharaan benih ikan mas F-1 terseleksi maupun kontrol relatif sama. Hal ini berdampak terhadap penampilan fenotipik pada kedua populasi tersebut tidak berbeda nyata.

\section{KESIMPULAN}

Laju pertumbuhan spesifik populasi benih ikan mas F-1 terseleksi sebesar 2,4\%/hari relatif lebih baik dibandingkan benih kontrol sebesar 2,3\%/hari. Laju pertumbuhan tersebut menghasilkan selisih bobot rata-rata individu antara kedua populasi pada akhir masa pembesaran sebesar 17,61 $\mathrm{g}$ atau setara dengan respons seleksi dari F-0 ke F-1 sebesar 7,29\%.
Nilai heritabilitas nyata $\left(\mathrm{h}^{2}\right)$ karakter pertumbuhan populasi ikan mas strain Rajadanu pada penelitian ini berada dalam kategori rendah sebesar 0,06.

\section{UCAPAN TERIMA KASIH}

Penelitian ini dibiayai oleh APBN melalui DIPA No. 0187/032-1 1.2.01/12/2012 pada Balai Penelitian Pemuliaan Ikan (BPPI), Sukamandi. Terima kasih disampaikan kepada Lamanto, S.Pi., staf peneliti BPPI, dan semua teknisi yang terlibat dalam kegiatan penelitian ini, Listiyo Dharmawanto, Supriyanto, Nurfansuri, dan Nikmatullah.

\section{DAFTAR ACUAN}

Andersen, O., \& Hayes, B. (2004). Population genetic. In Gjedrem, T. (Ed.), Selection and Breeding Program in Aquaculture, p. 23-33.

Ariyanto, D., Hayuningtyas, E.P., \& Syahputra, 
K. (2010). Koleksi dan karakterisasi populasi ikan mas sebagai bahan pembentuk ikan mas tahan KHV. Seminar hasil penelitian LRPTBPAT tahun 2010. Sukamandi, 1314 Desember 2010, $9 \mathrm{hlm}$.

Ariyanto, D., Hayuningtyas, E.P., \& Syahputra, K. (2011a). Seleksi karakter pertumbuhan ikan mas tahan KHV. Seminar hasil penelitian BPPI tahun 2011. Sukamandi, 27-28 Desember 2011, $15 \mathrm{hlm}$.

Ariyanto, D., Hayuningtyas, E.P., \& Syahputra, K. (2011b). Evaluasi daya tahan 3 strain ikan mas terhadap infeksi penyakit koi herpesvirus. Seminar Nasional Masyarakat Akuakultur Indonesia. Semarang, 2-3 Desember 2011, $10 \mathrm{hlm}$.

Boyd, C.E. (1990). Water quality in pond for aquaculture. Auburn University Press. Alabama, $482 \mathrm{pp}$.

Brody, T., Wohlfarth, G., Hulata, G., \& Moav, R. (1980). Application of electrophoretic genetic markers to fishbreeding. IV. Assessment of breeding value of full sib families. Aquaculture, 24, 175-186.

Falconer, D.S., \& Mackay, T.F.Chatche. (1996). Introduction to quantitative genetics. $4^{\text {th }}$ Ed. Longman. England, 464 pp.

Fjalestad, K.T. (2004). Breeding strategy. In Gjedrem, T. (Ed.), Selection and Breeding Program in Aquaculture, p. 145-158.

Hardjosubroto, W. 1994. Aplikasi pemuliabiakan ternak di lapangan. PT Grasindo Indonesia. Jakarta, $284 \mathrm{hlm}$.

Hayuningtyas, E.P., Syahputra, K., \& Ariyanto, D. (2011). Karakterisasi genetik lima strain ikan mas (Cyprinus carpio) dengan metode randomly amplified polymorphic DNA (RAPD). Prosiding FITA 201 1. Denpasar, hlm. 1,183-1,191.

Hayuningtyas, E.P., Ariyanto, D., \& Syahputra, K. (2013). Hubungan antara laju pertumbuhan dengan keberadaan gen major histocompatibility complex sebagai penciri molekuler ikan mas tahan penyakit. J. Ris. Akuakultur, 8(3), 383-391.
Hulata, G. (1995). A review of genetic improvement of the common carp (Cyprinus carpio L.) and other cyprinids by crossbreeding, hybridization, and selection. Aquaculture, 129, 143-155.

Moav, R. (1979). Genetic improvement in aquaculture industry. In Pillay, T.V.R. \& Dill, W. (Eds.), Advances in Aquaculture. Fishing News Books Ltd., Famham, Surrey. U.K., p. 610-622.

Moav, R., \& Wohlfarth, G. (1976). Two-way selection for growth rate in the common carp (Cyprinus carpio L.). Genetic, 82, 83-101.

Noor, R.R. (2000). Genetika ternak. Penebar Swadaya. Jakarta, $200 \mathrm{hlm}$.

Purdom, C.E. (1993). Genetics and fish breeding. Fish and Fisheries Series 8, Chapman \& Hall. London, $277 \mathrm{pp}$.

Rukmono, D. (2005). Kebijakan pengelolaan kesehatan ikan direktorat kesehatan ikan dan lingkungan. Di dalam Supriyadi, H. \& Priono, B. (Eds.), Strategi pengelolaan dan pengendalian penyakit KHV. Pusat Riset Perikanan Budidaya. Jakarta, hlm. 1-6.

Sonesson, A.K., Woolliams, J.A., \& Meuwissen, T.H.E. (2004). Kinship, relationship and inbreeding.In Gjedrem, T. (Ed.), Selection and Breeding Program in Aquaculture, $p$. 73-88.

Sunarto, A. (2005). Epidemiologi penyakit Koi Herpes Virus (KHV) di Indonesia. Strategi pengelolaan dan pengendalian penyakit KHV. Pusat Riset Perikanan Budidaya, hlm. 31-39.

Tave, D. 1993. Genetic for fish hatchery managers. $2^{\text {nd }}$ ed. AVI. Publishing Company. Inc. Connecticut, $418 \mathrm{pp}$.

Tave, D. 1996. Selective breeding programmes for medium sized fish farm. FAO. Technical papers. Rome, $122 \mathrm{pp}$.

Warwick, J.W., Astuti, M., \& Hardjasubroto, W. (1995). Pemuliabiakan ternak. Gadjah Mada University Pres. Yogyakarta, $485 \mathrm{hlm}$. 